\title{
The Effect of Supply Chain Management Strategy on Operational and Financial Performance
}

\author{
Rok Lee (iD
}

check for updates

Citation: Lee, R. The Effect of Supply Chain Management Strategy on Operational and Financial Performance. Sustainability 2021, 13, 5138. https://doi.org/10.3390/ su13095138

Academic Editor: António Abreu

Received: 3 April 2021

Accepted: 30 April 2021

Published: 4 May 2021

Publisher's Note: MDPI stays neutral with regard to jurisdictional claims in published maps and institutional affiliations.

Copyright: (C) 2021 by the author. Licensee MDPI, Basel, Switzerland. This article is an open access article distributed under the terms and conditions of the Creative Commons Attribution (CC BY) license (https:/ / creativecommons.org/licenses/by/ $4.0 /)$.
Department of LINC Plus Project Organization, Gyeongsang National University, Jinju 52828, Korea; roklee@gnu.ac.kr; Tel.: +82-10-6314-4004

\begin{abstract}
Given that small and medium manufacturing enterprises (SMEs) are key to national economic development, the application of supply chain strategies that support their sustainability is critical. This study aims to identify the effects of supply chain management (SCM) on the operational performance of SMEs in Korea, specifically considering organizational competencies. To achieve this, an empirical survey was conducted on 300 Korean manufacturing SMEs that had introduced SCM strategies. The relationships between the variables were analyzed through structural equation modeling. These show that specific SCM strategies and organizational competencies had a significant effect on overall business performance. Furthermore, the SCM strategies had a significant effect on SME organizational competencies. Additionally, we analyzed the mediating effect of organizational competencies on the effect of SCM strategy on overall business performance. We found that organizational competence mediated the effect of SCM strategy on operational performance, but not on financial performance. The study shows that introducing SCM strategies directly improves business performance and is closely related to competencies such as research and development, technology commercialization, production capability, and marketing capabilities. Consequently, a combination of SCM strategies and organizational competencies can generate sustainable overall business performance among SMEs.
\end{abstract}

Keywords: supply chain management strategy; operational performance; financial performance; manufacturing firms; Korea

\section{Introduction}

Today, small and medium manufacturing enterprises (SMEs) are improving their operational performance through more efficient management of the supply chain. These firms are innovating internal processes to ensure continuous competitiveness and sustainability in an international environment [1-3]. Since the supply chain includes organizations and activities involved in all processes, from the production of products or services to consumption, it is a central factor affecting firm performance. The supply chain achieves peak performance by improving the relationships among its firms to maximize profitability for all [4]. The aim of supply chain management (SCM) is to improve business performance and competitiveness through these strategic linkages. In other words, reinforcing the strategies formed in the supply chain is key to supply chain and business success. Given that SMEs are vital to national economic development, the introduction and application of supply chain strategies are critical to support their sustainability. However, these firms often have a lower ratio of production efficiency than large firms.

Several strategies have been suggested for coping with demand and supply in the supply chain. These include enterprise replenishment planning (ERP), vendor-managed inventory (VMI), collaborative planning, forecasting, and replenishment (CPFR), warehouse management systems (WMS), outsourcing strategies, and organizational competencies $[5,6]$.

Disney and Towill [7] state that in the collaborative relationships between suppliers and distributors, the ownership of products is transferred to the distributors at the time the 
distributors sell the products to consumers. The introduction of supply chain strategies can make information exchange among the firms in the chain more efficient, and reduce, for example, the bullwhip effect, where there are swings in inventory up the chain among firms farther removed from the customer [8]. Moreover, these strategies can increase the level of cooperation between distributors and suppliers, reducing lead times for delivery as well as the rate of product shortage [5].

In terms of the introduction of ERP, this approach can be based on a common repository that integrates various disparate systems into one database to streamline workflow. The CPFR strategy enables an accurate sales forecast, which can reduce the bullwhip effect as well, improving any scarcity of products or excessive inventory and customer service levels [9]. In the WMS strategy, the warehouses are managed together so that inventory information can reduce inventory in the supply chain effectively. In such cases, SCM strategies have a significant effect on operational and financial performance. This implies that the integrated operation of the supply chain, supported by the studies of Mentzer et al. [10] and Alfalla-Luque et al. [11], will have a positive effect on operational inventory management and, ultimately, on financial performance through the management of cost, quality, inventory, and delivery.

Recently, inter-firm supply chain strategies have been shown to have a positive effect on achieving a common purpose in all areas, ranging from procurement to production, distribution, and sales in terms of efficiency. However, most studies to date, for example, by Closs et al. [12], Lee [13], Mentzer et al. [10], and Meixell and Gargeya [14], have been limited to applying these conclusions to SMEs using research on large firms from a resource-based view [12-15].

The fourth industrial revolution has been led by sweeping internal and external changes, based on the adoption and spread of core element technologies such as the Internet of things, cloud computing, big data, mobile systems, and artificial intelligence. Thus, the introduction of unique strategies for the survival and growth of SMEs is a top priority for performance amid these fast-spreading changes.

However, the time has come for a fundamental review of the SCM strategies of manufacturing companies, based on the heavy and chemical industry-oriented economic growth structure, given the rapid reorganization of South Korea's industrial structure with a focus on high-tech industries such as IT, and diversification, flexibility and customer-led initiatives due to the globalization of corporate logistics activities and the spread of ecommerce. In particular, it is clear that the arrival of the fourth industrial revolution, along with the change in distribution structure, will allow the logistics network of manufacturing companies to become rapidly modular and networked. Therefore, the logistics supply strategy at the manufacturing company level needs a policy review to improve corporate operation performance through combination with organizational capabilities [16].

This study is aimed at determining the relationship between organizational competency and operational performance of SCM strategy in companies responding most rapidly at the interface of changes in the industrial and economic environment, proposing a strategic change in direction of the logistics facility policy for supply and operational performance through analysis of the relationship between SCM strategy and the organizational competence of manufacturers. This, in turn, will change many of the basis of major logistics management strategies, such as the master logistics facility development plan and the basic logistics plan of companies that determine the basic direction of logistics policy $[1,17]$.

As a manufacturing powerhouse, Korean firms have been implementing competitive integrated information systems for ERP to drive SCM efficiency based on factory automation. The effects of centralized ERP and core competence management on operational and financial performance in large firms have been confirmed, but the effects on SMEs have yet to be verified [18-21]. This study fills this gap in the literature in two ways, firstly by focusing specifically on SMEs, and secondly, by identifying the SCM strategies that 
improve business operation performance among SMEs in the context of the situation in Korea, where SMEs play a crucial role in the economy.

As the competitive dimension of manufacturing shifts from the rapidly changing management environment to supply chain competition, SCM strategy and organizational competency increase in importance in terms of their impact on business performance. This study seeks to suggest alternatives by confirming the SCM strategies that improve operational performance. Our research questions focus on two key variables: whether SCM strategies have a positive effect on SME performance and the role that organizational competencies play. To that end, we survey businesses in Korea to investigate the structural causality of the variable relationships through empirical surveys.

For this work, this study is conducted on the premise that a change in the SCM structure of small and medium-sized domestic manufacturing companies will act as a major factor that leads to a change in the logistics network strategy at the corporate level. First of all, the study determined SCM strategy change through characteristic analysis of the application of SCM in small and medium-sized domestic manufacturing companies, the effect of SCM strategy change on logistics organization competency, and the relationship between SCM strategy and operational performance at an enterprise level. It analyzes the effect of SCM strategy on organizational competence and operational performance, and draws conclusions through the congruence analysis between the result and SCM strategy to explore directions for change.

\section{Theoretical Background}

\subsection{Supply Chain Strategy}

It is difficult to achieve a competitive advantage through internal development alone in an organization [22]. With environmental changes and global competition intensifying, firms need to find ways to develop new competencies to adapt and maintain their competitiveness [23]. Hong and Jeong [24] imply that corporate supply chain strategies are key mechanisms that boost innovation and performance, suggesting that these can help firms adapt to environmental changes and aid their growth. Thus, an SCM strategy can help firms cope with these challenges.

The strategy of demand and supply planning, as suggested by Saleheen et al. [25], has been applied in various areas in organizational relationships in the supply chain and is a relevant component of VMI, ERP, CPFR, WMS, and outsourcing strategies, facilitating factors that improve corporate performance.

In terms of VMI, a strong flow of information across inter-firm relationships can establish a mutually agreed inventory level [26]. In terms of ERP, a comprehensive resource management system can be a next-generation business system as well as a set of applications that enable internal corporate business functions to be properly displayed in harmony [27].

In terms of CPFR, many studies have been conducted on average manufacturing firms in the SCM environment. In this regard, Ireland and Bruce [28] studied a connection between CPFR characteristics and corporate performance through SCM. Additionally, Yang and Fan [29] confirmed that average firms can increase the likelihood of supply chain stability, explaining that CPFR technology can have a positive effect on SCM performance. Competitive advantage increases sales in a crowded market consisting of multiple customers and suppliers, as the gains achieved through the introduction of CPFR and SCM impact return on investment from a financial perspective.

Lieb and Randall [30] refer to the reduction of logistics costs, the concentration of core capabilities, and increased efficiency of operations as benefits from logistics outsourcing, through an analysis of a third-party logistics service used by large American firms. Accordingly, we can infer that the supply chain acts as a catalyst that evokes core competencies and utilizes external logistics expertise, [31] while improving customer satisfaction to maximize business efficiency. Therefore, this SCM strategy is linked to an integrated information system to clearly plan company-wide resources, and has a very close relationship with 
the small- and medium-sized manufacturing industry, particularly in the supply chain strategy.

\subsection{Organizational Competence}

Competencies in supply chain integration reference important organizational strengths [32] that can maximize the collaborative management of intra- and inter-organizational processes $[33,34]$. They increase competitiveness by efficiently linking an organization's internal departments to SCM [35]. Several studies on organizational competencies have been undertaken in the context of the supply chain $[32,36]$. In recent studies, internal competencies have been conceptualized on three levels: internal integration, supplier integration, and customer integration [37-39]. A study by Shin et al. [40] found that organizational competencies have a positive effect on the operational performance of SMEs. Therefore, this study seeks to discover the relationship between internal integration and other variables in more detail by investigating firm capabilities, such as research and development (R\&D), technology commercialization, production, and marketing, as organizational competencies.

\subsection{Business Operational Performance}

Performance is conceptualized as the operational success of the firm, measured mainly in terms of costs, quality, flexibility, and delivery [11]. Mentzer et al. [10] indicate that increased organizational competencies between firms in the supply chain, and each firm's increased overall operational efficiency, affect performance. Moreover, firms are paying attention to various measures to accurately understand changes in performance resulting from supply chain integration. Narasimhan and Kim [41] indicate that corporate supply chain integration has a significant effect on business performance, while Kim [42] confirms that the level of SCM practice, competitive capability, and integration has a positive effect on performance. Moreover, other studies have confirmed that integration strategies in the supply chain have a significant effect on operational [43-46] and development performance [47], and that financial performance is indirectly affected by these factors.

Judging from these studies, SCM has an independent and positive effect on business performance; however, the operational performance also depends on operational and financial factors, and the combination of SCM and business performance is expected to have a positive effect on financial performance such as increased sales and profits. Therefore, this study seeks to measure these factors by reflecting them as dependent variables of overall business performance.

\section{Research Design}

\subsection{Research Model}

As previously mentioned, the purpose of this study was to determine the empirical effects of supply chain management strategy on the operational and financial performance of SMEs, based on constructs from previous studies. The independent variables are the VMI, ERP, CPFR, WMS, and outsourcing; the mediating effect variables are R\&D, technology commercialization, production, and marketing capabilities, which are also components of the supply chain management and organizational competence, while the dependent variable is represented by operational performance and financial performance. These variables were analyzed using a structural equation model using the AMOS program, as per Figure 1. 


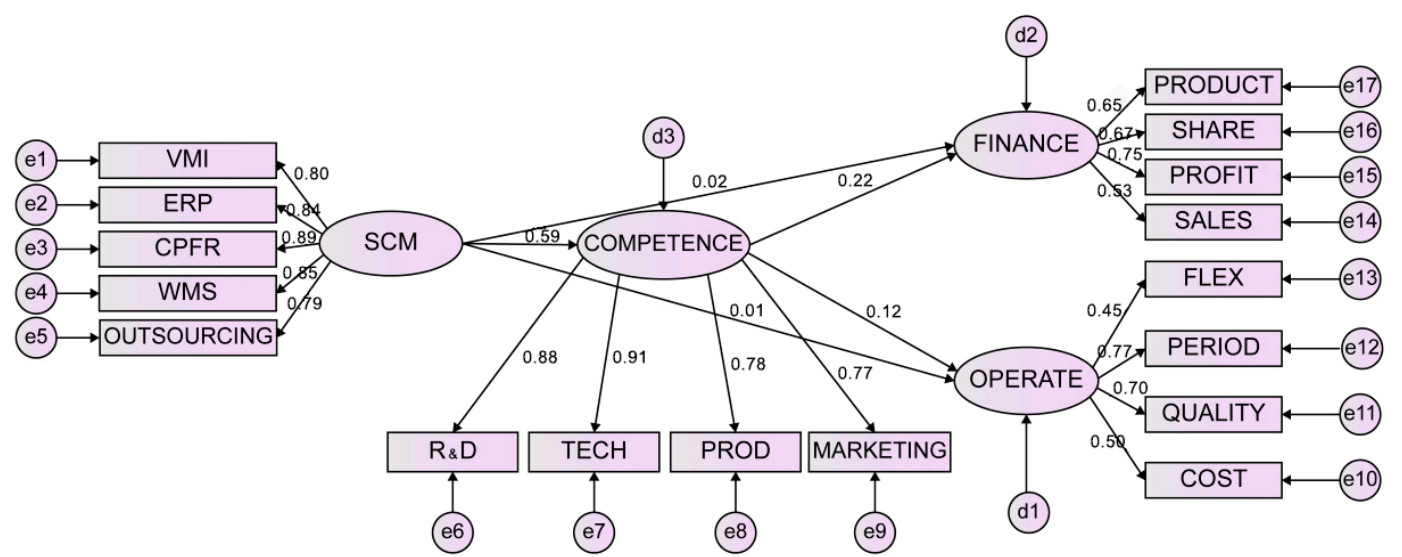

Figure 1. Research Model. Note: e is the measurement error.

\subsection{Questionnaire}

For empirical analysis, we conducted a survey spanning 60 days, from 1 May to 29 June 2019, of SMEs in Korea with SCM strategies. Only one questionnaire per firm was distributed, with the survey targeting hands-on workers through a combination of e-mail and direct site visits. A total of 340 structured self-administered questionnaires were distributed, of which 300 were used for the final analysis after excluding misleading testimonies and missing values. The respondents were primarily from four key manufacturing industries: automobile parts, marine engine parts, aircraft parts, and heavy equipment parts. Within the SMEs, both employees and managers were targeted to complete the survey. Please also see the Questionnaire in Appendix A.

\subsection{Definitions and Variable Measurements}

\subsubsection{SCM Strategy}

All variables in the study are partially modified to create the measurement items, based on prior studies. Following the method of Kim, Song and Kim, Rhee et al., Lee et al., and Lee and Lee, we used the five main SCM strategies of "VMI", "ERP", "CPFR", "WMS", and "OUTSOURCING" as the independent variables [20,21,48-50].

The survey of each construct and its indicators are measured on a five-point Likert scale.

\subsubsection{Organizational Competence}

Based on the study by Chun et al. [51], R\&D, technology commercialization, production, and marketing capabilities are adopted as the variables of organizational competence. Specifically, the authors point to the importance of the human resources directly involved in R\&D, the capability to embody external technologies, and the ability to promote technological cooperation with external stakeholders. Their indicators are partially modified to fit this research, composed of questionnaire items on $R \& D$ and technology commercialization capabilities. The production and marketing capabilities are measured on a five-point Likert scale.

\subsubsection{Overall Business Performance}

When measuring sensitive corporate data, there may be concerns regarding a low response rate. Moreover, when measuring financial data, there may be variations due to differences in inter-firm accounting practices [52]. Previous studies apply a broad range of self-administered cognitive measures to measure business performance [53]. Rosenzweig et al. [44], Swink et al. [54], and Schoenherra and Swink [36] define performance as the corporate capability to achieve positive operational results, compared to competitors and measure performance by comparing specific manufacturer performance with the industry 
average in the supply chain operation. In this study, operational performance and financial performance are used and measured on a five-point Likert scale (see Table 1).

Table 1. Questionnaire structure.

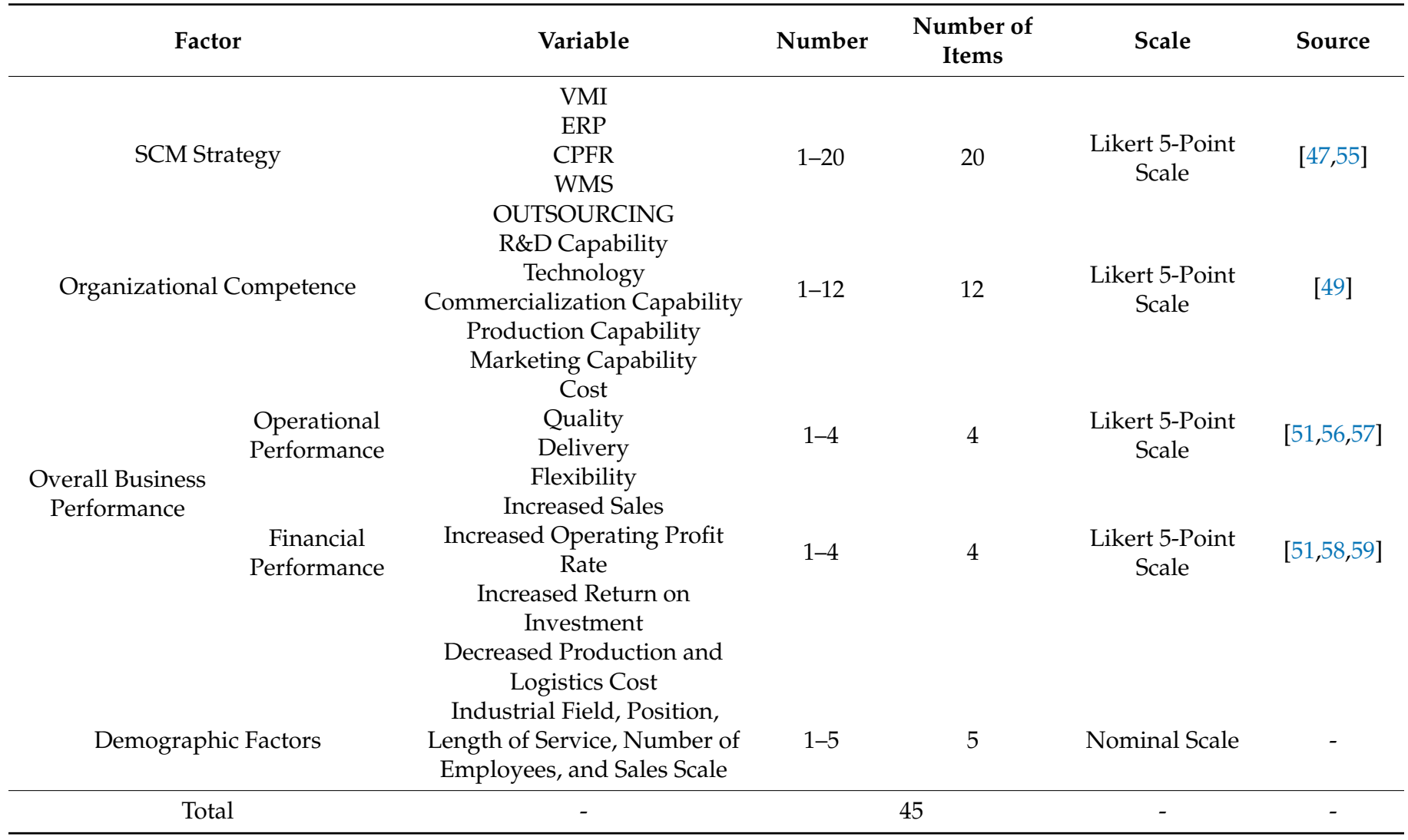

\section{Results}

4.1. Exploratory Factor Analysis and Reliability Analysis

The validity and reliability verification results for the variables are shown in Tables 2-5. The factor analysis shows that the Kaiser-Meyer-Olkin value was 0.828 , which indicates a slightly high correlation. In Bartlett's sphericity test, the approximate chi-square value was 2834.165, $p<0.001$. The absolute factor loading value for all items was greater than 0.4 , and the validity of the study was verified by grouping it into four variables. The reliability analysis shows that Cronbach's $\alpha$ values of $0.919,0.901,0.692$, and 0.742 , respectively, were larger than the standard 0.6 ; thus, the reliability of all variables was confirmed.

Table 2. Kaiser-Meyer-Olkin and Bartlett's Test Results.

\begin{tabular}{ccc}
\hline \multicolumn{2}{c}{ Kaiser-Meyer-Olkin Measure of Sample Adequacy } & $\mathbf{0 . 8 2 8}$ \\
\hline \multirow{3}{*}{ Bartlett's Sphericity Test } & Approximate Chi-Square & 2834.165 \\
& Degrees of Freedom & 136 \\
& Significance Probability & 0.000 \\
\hline
\end{tabular}


Table 3. Factor Loading Values of Variables.

\begin{tabular}{ccccc}
\hline Classification & & \multicolumn{3}{c}{ Component } \\
SCM Strategy & Organizational Competence & Financial Performance & Operational Performance \\
\hline VMI & 0.804 & 0.260 & -0.024 & 0.040 \\
ERP & 0.879 & 0.136 & 0.017 & -0.065 \\
CPFR & 0.864 & 0.253 & 0.026 & -0.016 \\
WMS & 0.826 & 0.277 & 0.011 & 0.056 \\
OUTSOURCING & 0.774 & 0.275 & 0.167 & 0.045 \\
R\&D Capability & 0.244 & 0.869 & 0.057 & 0.041 \\
Technology Commercialization & 0.227 & 0.894 & 0.096 & 0.031 \\
Capability & 0.363 & 0.764 & 0.051 & 0.033 \\
Production Capability & 0.434 & 0.712 & 0.018 & 0.016 \\
Marketing Capability & -0.232 & 0.197 & 0.320 & 0.580 \\
Cost & -0.005 & -0.045 & -0.070 & 0.853 \\
Quality & 0.127 & 0.039 & 0.067 & 0.822 \\
Delivery & 0.077 & -0.026 & 0.454 & 0.499 \\
Flexibility & -0.046 & -0.035 & 0.694 & 0.111 \\
Increased Sales & 0.147 & 0.130 & 0.779 & 0.100 \\
Increased Operating Profit Rate & -0.090 & 0.240 & 0.734 & -0.036 \\
Decreased Production and & -0.128 & -0.081 & 0.747 & 0.053 \\
Logistics Cost & & & \\
\hline
\end{tabular}

Table 4. Reliability.

\begin{tabular}{ccc}
\hline Classification & Number of Items & Cronbach's $\boldsymbol{\alpha}$ \\
\hline SCM Strategy & 5 & 0.919 \\
Organizational Competence & 4 & 0.901 \\
Operational Performance & 4 & 0.692 \\
Financial Performance & 4 & 0.742 \\
\hline
\end{tabular}

Table 5. General characteristics of the respondents.

\begin{tabular}{|c|c|c|c|}
\hline \multicolumn{2}{|r|}{ Category } & \multirow{2}{*}{$\begin{array}{c}\text { Frequency } \\
67\end{array}$} & \multirow{2}{*}{$\begin{array}{c}\text { Ratio (\%) } \\
22.3\end{array}$} \\
\hline \multirow{6}{*}{ Industrial Sector } & Automobile Parts & & \\
\hline & Marine Engine Parts & 35 & 11.7 \\
\hline & Aircraft Parts & 42 & 14.0 \\
\hline & Heavy Equipment Parts & 70 & 23.3 \\
\hline & Other & 86 & 28.7 \\
\hline & Employee & 20 & 6.7 \\
\hline \multirow{4}{*}{ Position } & Deputy & 51 & 17.0 \\
\hline & Section Chief & 27 & 9.0 \\
\hline & Deputy Department Head/Department Head & 21 & 7.0 \\
\hline & Executive & 82 & 27.3 \\
\hline \multirow{7}{*}{ Length of Service } & Chief Executive Officer & 99 & 33.0 \\
\hline & Under 2 Years & 39 & 13.0 \\
\hline & 2 Years to 5 Years & 11 & 3.7 \\
\hline & 5 Years to 8 Years & 101 & 33.7 \\
\hline & 8 Years to 10 Years & 99 & 33.0 \\
\hline & Over 10 Years & 50 & 16.7 \\
\hline & Under 50 persons & 79 & 26.3 \\
\hline Number of & 50 persons to 100 persons & 108 & 36.0 \\
\hline Employees & 100 persons to 200 persons & 74 & 24.7 \\
\hline \multirow{5}{*}{ Sales Scale (KR\#) } & Over 200 persons & 39 & 13.0 \\
\hline & Under 5 Billion & 48 & 16.0 \\
\hline & 5 Billion to 10 Billion & 82 & 27.3 \\
\hline & 10 Billion to 20 Billion & 100 & 33.3 \\
\hline & Over 20 Billion & 70 & 23.3 \\
\hline \multicolumn{2}{|r|}{ Total } & 300 & 100.0 \\
\hline
\end{tabular}




\subsection{Hypotheses Development}

Kang and Moon [60] state that firms should supplement their missing capabilities through alternative strategies in the supply chain, because it is difficult to secure a competitive advantage in all areas with limited resources. Consequently, they should focus on their core strengths for efficient management.

As stated, a supply chain strategy is necessary for firms to improve performance and, ultimately, increase their competencies. Based on these arguments, we established the following hypotheses.

Hypothesis 1. The SCM strategy will have a positive effect on overall business performance in SMEs.

Hypothesis 1.1. The SCM strategy will have a positive effect on operational performance in SMEs.

Hypothesis 1.2. The SCM strategy will have a positive effect on financial performance in SMEs.

The supply chain strategy has a direct effect on overall business performance such as quality, cost, delivery, and flexibility, depending on the organization's competencies. Lee and Kim [57] state that supply chain strategies can improve overall business performance depending on the organization's research, technology commercialization, and marketing capabilities. Specifically, supply chain strategies can improve business performance by reducing costs, improving quality, improving delivery performance, and providing flexibility by maximizing each firm's organizational competencies. As such, the supply chain is a mechanism that can enhance firm performance [61]. Based on these arguments, we established the following hypotheses.

Hypothesis 2. Organizational competence will have a positive effect on overall business performance in SMEs.

Hypothesis 2.1. Organizational competence will have a positive effect on operational performance in SMEs.

Hypothesis 2.2. Organizational competence will have a positive effect on financial performance in SMEs.

A firm's supply chain strategy is affected by environmental uncertainty [61]. Lee and Kim [57] state that supply chain strategies can support business competitiveness by improving financial performance. Supply chain strategies pursued by firms can reduce environmental uncertainty and improve their performance, as they support faster delivery and flexible customer response capabilities. Based on these arguments, we established the following Hypothesis.

Hypothesis 3. SCM strategy will have a positive effect on organizational competence in SMEs.

The complexities of a dynamic market environment include changes in quality, price, technological development, and cross-industry knowledge transfer. Accurate forecasting is difficult, placing considerable pressure on firms. SMEs must establish effective supply chain strategies to cope with such environmental uncertainty. Moon and Huh [23] state that business performance depends on SME organizational competencies to implement SCM strategies. The management and systematization of organizational competencies are critical to SCM; business performance depends on the mediation of internal competencies such as R\&D, technology commercialization, and production and marketing capabilities. Based on these arguments, we established the following hypotheses.

Hypothesis 4. Organizational competencies play a mediating role in the effect of SCM strategy on overall business performance in SMEs. 
Hypothesis 4.1. Organizational competencies play a mediating role in the effect of SCM strategy on operational performance in SMEs.

Hypothesis 4.2. Organizational competencies play a mediating role in the effect of SCM strategy on financial performance in SMEs.

\subsection{Data}

The general demographic characteristics of the surveyed firms are shown in Table 1. In the industrial sector, companies manufacturing heavy equipment had the highest frequency in the sample. In terms of position, chief executive officers were the most frequent respondents (the highest ratio), followed by company executives, deputies, section chiefs, deputy department heads/department heads, or employees. In terms of length of service, $33.7 \%$ of the respondents had been in the company for five to eight years. In terms of the number of employees in the firm, $36.0 \%$ of the respondent firms have 50 to 100 employees. In terms of sales, $33.3 \%$ of the respondent firms had sales figures of between KR $\# 10$ billion and KR\#20 billion.

\subsection{Confirmatory Factor Analysis}

The results of confirmatory factor analysis for the variables are shown in Table 6. Since all variables satisfied the standardized factor loading value of 0.5 or higher, the standardized critical ratio (CR) of 1.965 or higher, the standardized construct reliability of 0.7 or higher, and the standard deviation of 0.5 or higher, they were used in the analysis without modification as validity was determined to be acceptable.

Table 6. Confirmatory Factor Analysis.

\begin{tabular}{|c|c|c|c|c|c|}
\hline & Classification & $\begin{array}{c}\text { Factor } \\
\text { Loading Value }\end{array}$ & Critical Ratio & $\begin{array}{l}\text { Construct } \\
\text { Reliability }\end{array}$ & $\begin{array}{l}\text { Standard } \\
\text { Deviation }\end{array}$ \\
\hline \multirow{5}{*}{ SCM Strategy } & VMI & 0.803 & 16.977 & \multirow{5}{*}{0.96} & \multirow{5}{*}{0.82} \\
\hline & ERP & 0.838 & 18.218 & & \\
\hline & CPFR & 0.892 & 20.239 & & \\
\hline & WMS & 0.852 & & & \\
\hline & OUTSOURCING & 0.793 & 16.67 & & \\
\hline \multirow{4}{*}{$\begin{array}{l}\text { Organizational } \\
\text { Competence }\end{array}$} & R\&D Capability & 0.881 & 16.471 & \multirow{4}{*}{0.93} & \multirow{4}{*}{0.77} \\
\hline & Technology Commercialization Capability & 0.914 & 17.111 & & \\
\hline & Production Capability & 0.781 & 14.256 & & \\
\hline & Marketing Capability & 0.77 & & & \\
\hline \multirow{4}{*}{$\begin{array}{l}\text { Operational } \\
\text { Performance }\end{array}$} & Cost & 0.533 & 5.993 & \multirow{4}{*}{0.81} & \multirow{4}{*}{0.52} \\
\hline & Quality & 0.672 & 6.647 & & \\
\hline & Delivery & 0.748 & 6.732 & & \\
\hline & Flexibility & 0.488 & & & \\
\hline \multirow{4}{*}{$\begin{array}{c}\text { Financial } \\
\text { Performance }\end{array}$} & Increased Sales & 0.535 & 7.37 & \multirow{4}{*}{0.88} & \multirow{4}{*}{0.64} \\
\hline & Increased Operating Profit Rate & 0.754 & 9.05 & & \\
\hline & Increased Return on Investment & 0.658 & 8.581 & & \\
\hline & Decreased Production and Logistics Cost & 0.655 & & & \\
\hline
\end{tabular}

\subsection{Path Analysis}

The fitness results of the path analysis are shown in Table 7.

Table 7. Fitness of Research Model.

\begin{tabular}{cccccccc}
\hline Classification & GFI & RMR & RMSEA & NFI & CFI & TLI & AGFI \\
\hline Analysis Result & 0.942 & 0.045 & 0.003 & 0.937 & 0.970 & 0.945 & 0.917 \\
Fitness Reference Value & $\geq 0.9$ & $\leq 0.05$ & $\leq 0.05$ & $\geq 0.9$ & $\geq 0.9$ & $\geq 0.9$ & $\geq 0.9$ \\
\hline
\end{tabular}

Note: GFI is the goodness of fit index, RMR is the root mean square residual, RMSEA is the root mean square error of approximation, NFI is the normed fit index, CFI is the comparative fit index, TLI is the Tucker-Lewis index, and AGIF is the adjusted goodness-of-fit-index. 
The fitness index of the model shows: chi-square $=473.304$, degrees of freedom $=114$, $\mathrm{GFI}=0.942, \mathrm{RMR}=0.045, \mathrm{RMSEA}=0.003, \mathrm{NFI}=0.937, \mathrm{CFI}=0.970, \mathrm{TLI}=0.945$, and AGFI = 0.987. GFI, NFI, AGFI, CFI, and TLI values were 0.9 or higher and RMR and RMSEA were 0.05 or lower. Thus, the fitness of the path analysis for this model was verified [62].

The final path model is shown in Table 8. Organizational competencies, as well as SCM strategies, were confirmed to have a significant effect on the firm's operational and financial performance. Moreover, SCM strategies were shown to have a significant effect on organizational competencies. These results support hypotheses 1,2 , and 3 . The specifics are as follows.

Table 8. Final Path Analysis.

\begin{tabular}{|c|c|c|c|c|c|c|c|c|c|}
\hline \multicolumn{4}{|c|}{ Path } & \multirow{2}{*}{$\begin{array}{c}\text { B } \\
-0.004\end{array}$} & \multirow{2}{*}{$\begin{array}{c}\boldsymbol{\beta} \\
-0.007\end{array}$} & \multirow{2}{*}{$\begin{array}{c}\text { SE } \\
0.055\end{array}$} & \multirow{2}{*}{$\begin{array}{c}\text { CR } \\
-0.079\end{array}$} & \multirow{2}{*}{$\begin{array}{c}p \\
0.037\end{array}$} & \multirow{2}{*}{$\begin{array}{c}\text { Hypothesis Supported/ } \\
\text { Rejected }\end{array}$} \\
\hline H1-1 & SCM Strategy & $\rightarrow$ & $\begin{array}{c}\text { Business } \\
\text { Performance }\end{array}$ & & & & & & \\
\hline H1-2 & SCM Strategy & $\rightarrow$ & $\begin{array}{c}\text { Financial } \\
\text { Performance }\end{array}$ & 0.015 & 0.022 & 0.060 & 0.248 & 0.004 & Supported \\
\hline H2-1 & $\begin{array}{c}\text { Organizational } \\
\text { Competence }\end{array}$ & $\rightarrow$ & $\begin{array}{l}\text { Operational } \\
\text { Performance }\end{array}$ & 0.075 & 0.117 & 0.058 & 1.281 & $* * *$ & Supported \\
\hline $\mathrm{H} 2-2$ & $\begin{array}{c}\text { Organizational } \\
\text { Competence }\end{array}$ & $\rightarrow$ & $\begin{array}{c}\text { Financial } \\
\text { Performance }\end{array}$ & 0.156 & 0.219 & 0.064 & 2.435 & 0.015 & Supported \\
\hline H3 & SCM Strategy & $\rightarrow$ & $\begin{array}{c}\text { Organizational } \\
\text { Competence }\end{array}$ & 0.574 & 0.595 & 0.061 & 9.456 & $* * *$ & Supported \\
\hline
\end{tabular}

Note: B represents Regression Weights, $\beta$ is the Standardized Regression Weight, SE is the standard error, CR is the critical ratio, and $p$ is the probability. ${ }^{* * *} p<0.001$.

The path coefficients of Hypothesis 1 (SCM strategy will have a positive effect on the overall business performance of SMEs) were -0.007 (CR $=-0.079, p=0.037)$ for operational performance and $0.115(C R=0.248, p=0.004)$ for financial performance; thus, the SCM strategies were shown to have a significant effect on overall business performance, supporting Hypothesis 1.

The path coefficients of Hypothesis 2 (organizational competence will have a positive effect on the overall business performance in SMEs) were 0.117 (CR $=1.281, p<0.001)$ for operational performance and $0.219(\mathrm{CR}=2.435, p=0.015)$ for financial performance; thus, organizational competence were shown to have a significant effect on overall business performance, supporting Hypothesis 2.

The path coefficient of Hypothesis 3 (SCM strategy will have a positive effect on the organizational competence in SMEs) was $0.574(\mathrm{CR}=9.456, p<0.001)$; thus, the SCM strategy had a significant effect on organizational competence, supporting Hypothesis 3.

\subsection{Mediation Analysis}

We analyzed the mediating effect of organizational competence on the effect of SCM strategy on overall business performance in SME manufacturing firms. Table 9 shows the results of the detailed mediating effect verification. The total effect, both direct and indirect, was verified through the bootstrapping method. The direct, indirect, and total effects of SCM strategy on operational performance were $-0.007(p>0.05), 0.070(p<0.05)$, and 0.062 , respectively; however, the direct, indirect, and total effects of SCM strategy on financial performance were not significant. This meant that Hypothesis 4 was rejected. Organizational competence played a mediating role in the effect of SCM strategy only on operational performance, supporting Hypothesis 4.1 . 
Table 9. Mediation Results.

\begin{tabular}{|c|c|c|c|c|c|c|c|c|c|}
\hline & & & Path & & & $\begin{array}{c}\text { Total } \\
\text { Effect } \\
\text { (p) }\end{array}$ & $\begin{array}{l}\text { Direct } \\
\text { Effect } \\
\text { (p) }\end{array}$ & $\begin{array}{l}\text { Indirect } \\
\text { Effect } \\
\text { (p) }\end{array}$ & $\begin{array}{c}\text { Hypothesis } \\
\text { Support or Reject }\end{array}$ \\
\hline H4-1 & SCM Strategy & $\rightarrow$ & $\begin{array}{c}\text { Organizational } \\
\text { Competence }\end{array}$ & $\rightarrow$ & $\begin{array}{l}\text { Operational } \\
\text { Performance }\end{array}$ & $\begin{array}{c}0.062 \\
(0.409)\end{array}$ & $\begin{array}{l}-0.007 \\
(0.984)\end{array}$ & $\begin{array}{c}0.070 \\
(0.023)\end{array}$ & Support \\
\hline H4-2 & SCM Strategy & $\rightarrow$ & $\begin{array}{c}\text { Organizational } \\
\text { Competence }\end{array}$ & $\rightarrow$ & $\begin{array}{c}\text { Financial } \\
\text { Performance }\end{array}$ & $\begin{array}{c}0.152 \\
(0.070)\end{array}$ & $\begin{array}{c}0.022 \\
(0.796)\end{array}$ & $\begin{array}{c}0.130 \\
(0.269)\end{array}$ & Reject \\
\hline
\end{tabular}

\subsection{Discussion}

We analyzed the relationships of the variables and found the following. First, SCM strategies and organizational competencies had a significant effect on the operational and financial performance of the SMEs surveyed. Additionally, SCM strategies had a significant effect on SME organizational competency. This shows that firms with SCM strategies had relatively higher organizational competencies and operational performances than those without SCM strategies. However, the underlying cause is that enhanced organizational competencies played a mediating role. Second, organizational competence played a mediating role in the effect of SCM strategy only on operational performance, while the Hypothesis on its mediating effect on financial performance was rejected. Firms with SCM strategies had relatively high organizational competencies, but this had no direct effect on improving their financial performance because their financial performance was affected by other factors such as interest rates, oil prices, and the economy.

The results herein support those of Min et al. [55] who stated that cooperative partnerships and ties with firms in the supply chain, as strategic measures of SMEs, have a significant effect on corporate performance.

In addition, the studies of Lee et al. [56] show differentiation from this study as industrial studies for bolstering SCM competency of domestic companies and discovering industrial and corporate promotion policies. In particular, the study of Lee et al. [56] performed quantitative analysis of various strategic changes and performances in the growth process of global logistics companies, which sets the direction in which domestic logistics manufacturing companies should change through a comparative analysis with major domestic logistics companies, and its value is as industrial research to support them in a policy manner. Liu and Lee [2] suggested a very close relationship between these related variables in the policy stance and implementation tasks of the policy discovery and system improvement for constructing rational logistics networks, and the development and operation of logistics networks for establishing strategic plans in the logistics sector. Compared with a number of papers directly related to the current study, this work shows differentiation in that Paulraj [57] mapped the direction of strategic change in logistics companies, given that similar researches for discovering logistics policies from the perspective of SCM have a similarity with the basic researches for establishing the corporate SCM analysis model, on the premise that the SCM system will affect the logistics system and efficiency of companies, and that the change of SCM strategy in overall companies affect corporate SCM.

If the corporate SCM strategy were led by top-down policies, this study is differentiated from existing research in that it attempted to change the strategic direction into consumer-oriented bottom-up logistics development, based on the change in the SCM strategy and network of industries and companies.

\section{Conclusions}

Our results prove that SCM strategies, such as VMI, ERP, CPFR, WMS, and outsourcing, have a direct impact on improving operational and financial performance among SMEs. Moreover, boosting an organization's capabilities, such as R\&D, technology commercialization, production, and marketing, has a positive effect on both operational and financial performance. Consequently, combining SCM strategies and organizational competencies will enhance operational and financial performance among these manufacturing firms. 
In the supply chain, firms operate in interdependent relationships as a chain of producers and assembly manufacturers in the process of producing, distributing, and selling various parts and raw materials. As such, SMEs can improve their corporate financial performance by maximizing their organizational competence, as a strategy to support SCM. In an environment where supply chain competition is attracting attention, SMEs can enhance their core competencies to increase the performance of the supply chain and thereby enhance their competitiveness. Furthermore, firms can discover new opportunities by improving their existing supply chains in the short term, and by exploring and developing new supply chains in the long term.

\subsection{Academic and Practical Implications for Corporate Management}

From an industrial perspective, this study highlights the need for integrated expansion with external customers and supplier partners in the supply chain, specifically among SMEs $[36,57,63,64]$. In terms of practical implications, it proved that SME manufacturers should proceed with supply chain competency development, drive external integration with customers and suppliers, and bolster internal competencies. In addition, more attention should be paid to the use of supply chain strategies. For manufacturers with limited resources or in the early stages of supply chain consolidation, it proved that integrating with customers and suppliers after internal process consolidation could also help maximize performance. It can be evaluated that all of these underscore the importance of SCM strategies and organizational competencies for the sustainable overall business performance of Korean SME manufacturing firms.

In particular, this study has industrial implications in that it classifies the factors of supply chain strategy and the factors of corporate organizational competence and operational performance in detail to identify the relationship between them, and in that it raises the need for expansion integrated with external customers and supply partners beyond the research focused on existing internal integration [36,63].

In addition, it has practical implications for corporate management. It was confirmed that it is desirable for manufacturers promoting organizational competency in supply chains to faithfully integrate internal functions and then promote external integration with customers and suppliers, and that manufacturers can maximize the performance of forming customer and supplier integration after achieving internal integration if they have limited resources in the early stages of supply chain integration efforts.

\subsection{Differentiation from Existing Research}

Although it was not possible to find domestic and foreign research directly related to this study, Paulraj [57] conducted basic research for establishing a corporate SCM analysis model through similar research for the discovery of logistics policies from the perspective of SCM, on the premise that the SCM system will affect corporate logistics systems and efficiency. This study has differentiation in that changes in corporate SCM strategy affected corporate SCM, and in that logistics companies drew the change direction of corporate strategy given this factor. In other words, if the corporate SCM strategy were led by topdown policies, this study is differentiated from existing research in that it attempted to change the strategic direction into consumer-oriented bottom-up logistics development, based on the change in the SCM strategy and network of industries and companies.

In addition, the studies of Lee et al. [56] has differentiation from this study as industrial research for bolstering the SCM competency of domestic companies and discovering industrial and corporate promotion policies. In particular, the study of Lee et al. [56] performed quantitative analysis of various strategic changes and performances in the growth process of global logistics companies, which sets the direction in which domestic logistics manufacturing companies should change through a comparative analysis of them with major domestic logistics companies, and has its value as industrial research to support them in a policy manner. Meanwhile, the study of Liu and Lee [2] has differentiation from this study in that it suggested the policy stance and implementation of policy discovery 
and system improvement for constructing rational logistics networks, and the development and operation of logistics networks for establishing strategic plans in the logistics sector as tasks of policy and promotion system for supporting the enhancement of SCM competency in logistics companies from a perspective of strengthening the competitiveness of shippers.

\subsection{Limitations of the Research}

In the recent supply chain environment, competition among supply chains is gradually attracting attention, and the way companies use their own resources can improve the performance of the supply chain and continuously strengthen the competitiveness [64]. This means that SMEs should also pay more attention to the use of supply chain strategy along with strengthening their internal core competency. In other words, efforts are required to discover efficiency and strengthening by improving existing supply chains in the short term, and new opportunities by exploring and developing new supply chains in the long term.

Companies will improve their financial performance by maximizing organizational competency as a strategy for bolstering the SCM competency of small and medium-sized manufacturing industry, in that they are not operated independently, but operate in an interdependent relationship with producers and assemblers in the production, distribution and sales processes of various parts and raw materials through the formation of supply chains and interaction.

In particular, this study is closely related to SMEs as a way of exploring SCM strategy and policy improvement for small and medium-sized manufacturing companies in South Korea, through analysis of the relationship between SCM strategy change, organizational competency and operational performance in shippers and logistics companies. Since case analysis for the characteristics of the SCM strategy change in manufacturing companies has not been expanded to the world market including Europe, the United States, and Japan, policy analysis and improvement alternatives using the results are limited to South Korea.

Finally, this study has some limitations. As the sample was specific to Korea and to manufacturing firms, the results may not be generalized to other countries or industries. Future research should apply the approach of this study to different countries and industries.

Funding: This research received no external funding.

Institutional Review Board Statement: Not applicable.

Informed Consent Statement: Not applicable.

Data Availability Statement: Not applicable.

Conflicts of Interest: The authors declare no conflict of interest. 


\section{Appendix A. Questionnaire}

Table A1. SCM strategies.

1. Your firm has built a VMI system infrastructure for continuous maintenance.

2. Your firm is actively using the VMI system after persuading business parties and stakeholders of its importance.

3. Your firm has improved work efficiency by using the VMI system.

4. Your firm has increased productivity by using the VMI system.

5. Your firm has built an ERP system infrastructure for continuous maintenance.

6. Your firm is actively using the ERP system after persuading business parties and stakeholders of its importance.

7. Your firm has improved work efficiency by using the VMI system.

8. Your firm has increased productivity by using the ERP system.

9. Your firm has built a CPFR system infrastructure for continuous maintenance.

10. Your firm is actively using the CPFR system after persuading business parties and stakeholders of its importance.

CPFR

11. Your firm has improved work efficiency by using the CPFR system.

12. Your firm has increased productivity by using the CPFR system.

13. Your firm has built a WMS system infrastructure for continuous maintenance.

WMS

14. Your firm is actively using the WMS system after persuading business parties and stakeholders of its importance.

15. Your firm has improved work efficiency by using the WMS system.

16. Your firm has increased productivity by using the WMS system.

17. You have built outsourcing infrastructure for continuous maintenance.

OUTSOURCING 18. Your firm is actively using outsourcing after persuading business parties and stakeholders of its importance.

19. Your firm has improved work efficiency by using outsourcing.

20. Your firm has increased productivity by using outsourcing. 
Table A2. Intra-firm organizational competences.

\begin{tabular}{|c|c|c|c|c|c|c|}
\hline & Evaluation Item & Strongly Agree & Agree & Neutral & Disagree & Strongly Disagree \\
\hline $\begin{array}{l}\text { R\&D Capability } \\
\text { Technology } \\
\text { Commercialization } \\
\text { Capability } \\
\text { Production } \\
\text { Capability } \\
\text { Marketing Capability }\end{array}$ & $\begin{array}{l}\text { 1. Your firm has a standardized process for new product (service) development. } \\
\text { 2. Your firm integrates and links internal resources closely. } \\
\text { 3. Your firm integrates R\&D, production, and marketing capabilities. } \\
\text { 4. Your firm works closely with external specialized agencies in connection with } \\
\text { technology commercialization. } \\
\text { 5. Your firm learns quickly about external technologies. } \\
\text { 6. Your firm has an excellent learning capability of technologies acquired from the } \\
\text { outside. } \\
\text { 7. Your firm is generally superior in product (service) production to other firms in the } \\
\text { same industry. } \\
\text { 8. Your firm has a generally high level of technology. } \\
\text { 9. Your firm has skilled personnel who develop technologies. } \\
\text { 10. Your firm analyzes the target market for the developed products to establish } \\
\text { systematic marketing strategies such as pricing and sales forecast. } \\
\text { 11. Your firm allocates the effective role of human resources in its organization to } \\
\text { support their work. } \\
\text { 12. Your firm cooperates internally on the opportunities and threats identified in the } \\
\text { market to look for alternatives. }\end{array}$ & & & & & \\
\hline & Evaluation Item & Strongly Agree & Agree & Neutral & Disagree & Strongly Disagree \\
\hline $\begin{array}{c}\text { Operational } \\
\text { Performance } \\
\text { Financial } \\
\text { Performance }\end{array}$ & $\begin{array}{l}\text { our firm has generally reduced manufacturing costs per unit. } \\
\text { our firm has decreased the defect rate of products. } \\
\text { our firm has generally shortened the lead time and new product development cycle. } \\
\text { our firm has improved flexibility in product design changes and production fluctuations. } \\
\text { 'our firm has increased its sales. } \\
\text { our firm has increased its operating profit rate. } \\
\text { our firm has increased its return on investment. } \\
\text { our firm has reduced its production and logistics costs. }\end{array}$ & & & & & \\
\hline
\end{tabular}




\section{General characteristics}

1. Which industry sectors do you belong to?

(1) Auto Parts (2) Marine Engine Parts

(3) Aircraft Parts (4) Heavy Equipment Parts

(5) Other

2. What is your position?

(1) Employee (2) Deputy Section Head

(3) Section Head (4) Deputy Department Head/Department Head

(5) Executive (6) Chief Executive Officer

3. How many years of work experience do you have?

(1) Under 2 Years (2) 2 Years to 5 Years

(3) 5 Years to 8 Years (4) 8 Years to 10 Years

(5) Over 10 Years

4. How many employees does your company have?

(1) Less Than 50 Persons (2) 51 Persons to 100 Persons

(3) 101 Persons to 200 Persons (4) More Than 201 Persons

5. What is the total revenue of your company (KRW)?

(1) Under 5 Billion (2) 5 Billion to 10 Billion

(3) 10 Billion to 20 Billion (4) Over 20.1 Billion

\section{References}

1. Zhou, H.; Shou, Y.; Zhai, X.; Li, L.; Wood, C.; Wu, X. Supply chain practice and information quality: A supply chain strategy study. Int. J. Prod. Econ. 2014, 147, 624-633. [CrossRef]

2. Liu, C.-L.; Lee, M.-Y. Integration, supply chain resilience, and service performance in third-party logistics providers. Int. J. Logist. Manag. 2018, 29, 5-21. [CrossRef]

3. Jermsittiparsert, K.; Sutduean, J.; Sriyakul, T.; Khumboon, R. The role of customer responsiveness in improving the external performance of an agile supply chain. Pol. J. Manag. Stud. 2019, 19, 206-217.

4. Stevenson, W.J.; Sum, C.C. Operations Management; McGraw-Hill/Irwin: New York, NY, USA, 2014.

5. Bendoly, E.; Jacobs, F.R. Strategic ERP Extension and Use; Stanford University Press: Stanford, CA, USA, 2005.

6. Tajbakhsh, A.; Hassini, E. Performance measurement of sustainable supply chains: A review and research questions. Int. J. Prod. Perform. Manag. 2015, 64, 744-783. [CrossRef]

7. Disney, S.M.; Towill, D.R. The effect of vendor managed inventory (VMI) dynamics on the Bullwhip Effect in supply chains. Int. J Prod. Econ. 2003, 85, 199-215. [CrossRef]

8. Claassen, M.J.; Van Weele, A.J.; Van Raaij, E.M. Performance outcomes and success factors of vendor managed inventory (VMI). Supply Chain Manag. 2008, 13, 406-414. [CrossRef]

9. Sherman, R.J. Collaborative planning, forecasting \& replenishment (CPFR): Realizing the promise of efficient consumer response through collaborative technology. J Market. Theory Pract. 1998, 6, 6-9. [CrossRef]

10. Mentzer, J.T.; DeWitt, W.; Keebler, J.S.; Min, S.H.; Nix, N.W.; Smith, C.D.; Zacharia, Z.G. Defining Supply Chain Management. J. Bus. Logist. 2001, 22, 1-25. [CrossRef]

11. Alfalla-Luque, R.; Marin-Garcia, J.A.; Medina-Lopez, C. An analysis of the direct and mediated effects of employee commitment and supply chain integration on organisational performance. Int. J. Prod. Econ. 2015, 162, 242-257. [CrossRef]

12. Closs, D.J.; Stank, T.P.; Keller, S.B. Performance Benefits of Supply Chain Logistical Integration. Transport. J. 2001, $41,32-46$.

13. Lee, H.L. Aligning supply chain strategies with product uncertainties. Calif. Manag. Rev. 2002, 44, 105-119. [CrossRef]

14. Meixell, M.J.; Gargeya, V.B. Global supply chain design: A literature review and critique. Transport. Res. Part E Logist. Transp. Rev. 2005, 41, 531-550. [CrossRef]

15. Fynes, B.; De Búrca, S.; Marshall, D. Environmental uncertainty, supply chain relationship quality and performance. J. Purch. Supply Manag. 2004, 10, 179-190. [CrossRef]

16. Attia, A.; Eldin, I.E. Organizational Learning, Knowledge Management Capability and Supply Chain Management Practices in the Saudi Food Industry. J. Knowl. Manag. 2018, 22, 1217-1242. [CrossRef]

17. Tseng, S.-M. The Impact of Knowledge Management Capabilities and Supplier Relationship Management on Corporate Performance. Int. J. Prod. Econ. 2014, 154, 39-47. [CrossRef] 
18. Wang, J.; Dai, J. Sustainable Supply Chain Management Practices and Performance. Ind. Manag. Data Syst. $2018,118,2-21$. [CrossRef]

19. Park, C.S. The relationship between supply chain integration and business performance: The moderating effects of firm size. Korean Manag. Rev. 2012, 41, 1501-1527.

20. Lee, S.H.; Han, K.S.; Kim, K.S. The effects of the introduction of RFID technology on SCM competitive advantage: Focusing on defense industry. J. Strateg. Manag. 2013, 16, 1-27.

21. Lee, C.-B.; Lee, J.-C. A classification of logistics outsourcing in the global automotive industry. Korea Logist. Rev. 2019, 91, 163-174. [CrossRef]

22. Yu, K.; Luo, B.N.; Feng, X.; Liu, J. Supply chain information integration, flexibility, and operational performance: An archival search and content analysis. Int. J. Logist. Manag. 2018, 29, 340-364. [CrossRef]

23. Moon, S.M.; Huh, M.G. Duet of exploitation and exploration: The multi-dimensional approach of organizational ambilaterality. Korean Manag. Rev. 2013, 42, 293-320.

24. Hong, P.; Jeong, J. Supply chain management practices of SMEs: From a business growth perspective. J. Enterprise Inform. Manag. 2006, 19, 292-302. [CrossRef]

25. Saleheen, F.; Habib, M.M.; Pathik, B.B.; Hanafi, Z. Demand and supply planning in retail operations. Int. J. Bus. Econ. Res. 2014, 3, 51-56. [CrossRef]

26. Kwak, D.-W.; Seo, Y.-J.; Mason, R. Investigating the relationship between supply chain innovation, risk management capabilities and competitive advantage in global supply chains. Int. J. Oper. Prod. Manag. 2018, 38, 2-21. [CrossRef]

27. Klaus, H.; Rosemann, M.; Gable, G.G. What is ERP? Inform. Syst. Frontiers 2000, 2, 141-162. [CrossRef]

28. Ireland, R.; Bruce, R. CPFR. Supply Chain Manag. Rev. 2000, 1, 80-88.

29. Yang, T.; Fan, W. Information management strategies and supply chain performance under demand disruptions. Int. J. Prod. Res. 2016, 54, 8-27. [CrossRef]

30. Lieb, R.C.; Randall, H.L. A comparison of the use of third-party logistics services by large American manufacturers, 1991, 1994, and 1995. J. Bus. Logist. 1996, 17, 305.

31. Sink, H.L.; Langley, C.J. A Managerial Framework for the Acquisition of Third-Party Logistics Service. J. Bus. Logist. 1997, 18, 163-189.

32. Leuschner, R.; Rogers, D.S.; Charvet, F.F. A meta-analysis of supply chain integration and firm performance. J. Supply Chain Manag. 2013, 49, 34-57. [CrossRef]

33. Flynn, B.B.; Huo, B.; Zhao, X. The impact of supply chain integration on performance: A contingency and configuration approach. J. Oper. Manag. 2010, 28, 58-71. [CrossRef]

34. Zhao, X.; Huo, B.; Flynn, B.B.; Yeung, J.H.Y. The impact of power and relationship commitment on the integration between manufacturers and customers in a supply chain. J. Oper. Manag. 2008, 26, 368-388. [CrossRef]

35. Park, S.W.; Kim, S.W. The establishment of SC integration architecture. J. Korean Prod. Oper. Manag. Soc. 2007, 18, 173-200.

36. Schoenherra, T.; Swink, M. Revisiting the arcs of integration: Cross-validations and extensions. J. Oper. Manag. 2012, 30, 99-115. [CrossRef]

37. Gunasekaran, A.; Ngai, E.W. Information systems in supply chain integration and management. Eur. J. Oper. Res. 2004, 159, 269-295. [CrossRef]

38. Rai, A.; Patnayakuni, R.; Seth, N. Firm performance impacts of digitally enabled supply chain integration capabilities. MIS Q. 2006, 30, 225-246. [CrossRef]

39. Huh, D.S.; Kim, K.S.; Choi, J.W. An exploratory comparison of supply chain integration practices of Korean and international manufacturing plants in automotive, electronics, and machinery industries. Korean Manag. Sci. Rev. 2008, 33, 101-118.

40. Shin, H.J.; Lee, J.-N.; Kim, D.-S.; Rhim, H. Strategic agility of Korean small and medium enterprises and its influence on operational and firm performance. Int. J. Prod. Econ. 2015, 168, 181-196. [CrossRef]

41. Narasimhan, R.; Kim, S.W. Effect of supply chain integration on the relationship between diversification and performance: Evidence from Japanese and Korean firms. J. Oper. Manag. 2002, 20, 303-323. [CrossRef]

42. Kim, S.W. An investigation on the direct and indirect effect of supply chain integration on firm performance. Int. J. Prod. Econ. 2009, 119, 328-346. [CrossRef]

43. O'Leary-Kelly, S.W.; Flores, B.E. The integration of manufacturing and marketing/ sales decisions: Impact on organizational performance. J. Oper. Manag. 2002, 20, 221-240. [CrossRef]

44. Al-Shboul, M.A.R.; Barber, K.D.; Garza-Reyes, J.A.; Kumar, V.; Abdi, M.R. The effect of supply chain management practices on supply chain and manufacturing firms' performance. J. Manuf. Technol. Manag. 2017, 28, 577-609. [CrossRef]

45. Germain, R.; Iyer, K.N.S. The interaction of internal and downstream integration and its association with performance. J. Bus. Logist. 2006, 27, 29-52. [CrossRef]

46. Narasimhan, R.; Swink, M.; Viswanathan, S. On decisions for integration implementation: An examination of complementarities between product-process technology integration and supply chain integration. Decis. Sci. 2010, 41, 355-372. [CrossRef]

47. Koufteros, X.A.; Vonderembse, M.; Jayaram, J. Internal and external integration for product development: The contingency effects of uncertainty, equivocality, and platform strategy. Decis. Sci. 2005, 36, 97-133. [CrossRef]

48. Kim, H.K. An empirical study on the influences of warehouse management system activity on logistics performance. Korean Corp. Manage. Rev. 2006, 13, 13-32. 
49. Song, J.G.; Kim, K.S. The effect of information sharing on ERP implementation: On the basis of an automobile case. J. Ind. Innov. 2010, 26, 147-173.

50. Rhee, M.-K.K.; Choi, H.J.; Park, S.-T. An exploratory study on the slow adoption of vendor managed inventory in manufacturing firms. J. Digit. Converg. 2015, 13, 77-87. [CrossRef]

51. Chun, J.K.; Shin, Y.J.; Bae, H.S. The effect of the technology innovation capabilities and supply chain management activities on the business innovation performance: Focused on the footwear industry in Korea. J. Ind. Innov. 2011, 27, 25-57.

52. Aghajari, N.; Amat Senin, A. Strategic Orientation and Dual Innovative Operation Strategies: Implications for Performance of Manufacturing SMEs. Asia Pac. J. Bus. Admin. 2014, 6, 127-147. [CrossRef]

53. Dean, J.W., Jr.; Snell, S.A. The strategic use of integrated manufacturing: An empirical examination. Strategic Manag. J. 1996, 17, 459-480. [CrossRef]

54. Swink, M.; Narasimhan, R.; Wang, C. Managing beyond the factory walls: Effects of four types of strategic integration on manufacturing plant performance. J. Oper. Manag. 2007, 25, 148-164. [CrossRef]

55. Min, S.; Kim, S.K.; Chen, H. Developing social identity and social capital for supply chain management. J. Bus. Logist. 2008, 29, 283-304. [CrossRef]

56. Lee, J.S.; Kim, S.K.; Lee, S.Y. Sustainable Supply Chain Capabilities: Accumulation, Strategic Types and Performance. Sustainability 2016, 8, 503. [CrossRef]

57. Paulraj, A. Understanding the relationships between internal resources and capabilities, sustainable supply chain management and organizational sustainability. J. Supply Chain Manag. 2011, 47, 19-37. [CrossRef]

58. Olson, E.M.; Walker, O.C., Jr.; Ruekert, R.W.; Bonner, J.M. Patterns of cooperation during new product development among marketing, operations and R\&D: Implications for project performance. J. Prod. Innov. Manag. 2001, 18, 258-271. [CrossRef]

59. Lee, S.-B.; Kim, C.-S. The effect of supply chain search and application strategies on corporate operational performance: Focused on the mediating effect of organizational capability. J. Korea Manag. Eng. Acad. -Ind. Coop. Soc. 2017, 18, 423-433. [CrossRef]

60. Kang, S.B.; Moon, T.S. An empirical study on the impact of IT competence on supply chain performance through supply chain dynamic capabilities. Korean Manag. Rev. 2014, 43, 245-272.

61. Love, J.H.; Roper, S. Organizing innovation: Complementarities between cross functional teams. Technovation 2009, 29, 192-203. [CrossRef]

62. Hair, J.F., Jr.; Sarstedt, M.; Ringle, C.M.; Gudergan, S.P. Advanced Issues in Partial Least Squares Structural Equation Modeling; Sage Publications: New York, NY, USA, 2017; ISBN 1483377385.

63. Lee, N.; Yoo, S.H.; Jung, D. The Impact of Internal and External Supply Chain Integration on New Product Development. J. Korean Prod. Oper. Manag. 2019, 30, 327-343.

64. Ralston, P.M.; Blackhurst, J.; Cantor, D.E.; Crum, M.R. A Structure-conduct-performance perspective of how strategic supply chain integration affects firm performance. J. Supply Chain Manag. 2015, 51, 47-64. [CrossRef] 